\title{
Fagre nye arbejdsliv?
}

\section{- set gennem fire fremtrædende kritisk- sociologiske samtidsdiagnoser}

\author{
Michael Hviid Jacobsen \& Anders Petersen
}

'Prekarisering' er et begreb, der i disse år er på mange sociologers læber, fordi det tilsyneladende indfanger den nye form for usikkerhed, der karakteriserer nutidens samfund i almindelighed og arbejdsmarked og arbejdsliv i særdeleshed. Imidlertid er det langt fra første gang, at sociologer kritisk dissekerer, diagnosticerer og tilbyder farverige kritiske begreber til at beskrive tingenes tilstand i relation til arbejdslivet. Denne artikel introducerer til fire forskellige kritisk-sociologiske samtidsdiagnoser over nutidens arbejdsliv: 'fleksibiliseringsdiagnosen' (f.eks. ved Richard Sennett), 'brasilianiserings/balkaniseringsdiagnosen' (f.eks. ved Ulrich Beck og Zygmunt Bauman), 'kommercialiseringsdiagnosen' (f.eks. ved Arlie R. Hochschild) og 'prekariseringsdiagnosen' (f.eks. ved Guy Standing). Alle disse samtidsdiagnoser tilbyder et særligt kritisk blik både på de strukturelle, de kulturelle og de individuelle forhold, der tilsyneladende i stigende grad karakteriserer nutidens arbejdsmarked og arbejdsliv. Afslutningsvis diskuterer artiklen, hvorvidt disse fire samtidsdiagnoser tilbyder noget nyt i forhold til eksisterende sociologisk viden, hvorvidt de rammer plet i deres kritik, og særligt hvorvidt og hvordan den nyere 'prekariseringsdiagnose' adskiller sig fra de andre omtalte samtidsdiagnoser.

\section{Indledning}

Den engelske forfatter Aldous Huxley har inspireret til denne artikels valg af titel. Da han i 1932 udgav sin berømte dystopiske roman Fagre nye verden (Brave New World), var det langt fra som en hyldest til det kommende samfund, han beskrev i bogen, men derimod som en bidende men også satirisk kritik af den fremtid han frygtede ventede forude. Faktisk var der ifølge Huxley intet fagert ved den fagre nye verden, men snarere en verden præget af forfalds- og undergangstendenser. Det er denne kritiske indstilling, som kan genfindes i flere af de i denne artikel præsenterede sociologiske samtidsdiagnoser. Og samtidsdiagnoser er en iboende del af sociologiens hjerteblod. Ifølge de to tyske sociologer Ulrich Beck og Wolfgang Bon $\beta$ skal sociologien varetage tre hovedopgaver: For det første teoretisk grundbegrebskonstruktion, for det andet empirisk afprøvning af teoretiske antagelser og for det tredje samtidsdiagnostik (Beck \& Bon $\beta$ 2001:63). At bedrive samtidsdiagnostik involverer i bund og grund en ambition om grundlæggende at bestemme og kritisk at bedømme karakteren af det samfund, vi lever i (Rasborg 2003:120). Betegnelsen 'samtidsdiagnose' referer til noget specifikt 
- det handler om at påpege de problemer, som det beskrevne samfund konfronterer. Man kan sige, at sociologisk samtidsdiagnose, lige siden disciplinens spæde grundlæggelse for halvandet århundrede siden, har beskæftiget sig med at diagnosticere samfundets sygdomstegn, lidelser eller patologier. Både sociologiske klassikere som Karl Marx, Émile Durkheim, Max Weber og Georg Simmel skrev indgående om, hvorledes bruddet fra det traditionelle til det moderne samfund indebar fremmedgørelse, anomisk selvmord, rationalitetens jernbur og tiltagende individuel blaserthed. Klassikerne skrev med håbet om potentielle samfundsforbedringer for øje. De konstaterede ikke blot, hvordan verden nu engang var, men tillod sig også at komme med (om end ofte kun vage) handlingsanvisninger. Denne type af samtidsdiagnose er fortsat op igennem sociologiens historie. I sin berømte bog Den sociologiske fantasi fra 1959 beskrev den amerikanske sociolog Charles Wright Mills eksempelvis, hvordan hans samtid var kendetegnet ved en særlig utryghedsoplevelse, hvor mennesker oplevede, at de var fanget i en fælde, og hvor de følte, at de ikke kunne gennemskue det samfund, de var en del af, eller deres egen livssituation (Mills 1959/2002). Mills mente, at en af mulighederne for at forstå denne utryghed, og måske gennem forståelse både at kunne reducere utrygheden og bidrage til en forbedring af kvaliteten af menneskelivet, var gennem 'den sociologiske fantasi', som han beskrev som et dobbeltblik på samfundet, hvor den gensidige påvirkning mellem samfundsstruktur og livsbiografi blev sat i relief. Denne fantasi ville betyde, at man for det første kunne forstå, at ens liv var formet af kræfter, som man umiddelbart selv ikke havde kontrol over, men for det andet også, at det blev tydeligt, at man faktisk gennem viden og en kritisk sans kunne bidrage til at ændre det samfund, som man er en del af. Måske var det ikke andet end en grandios forhåbning på vegne af en kritisk sociolog, at netop en sociologisk fantasi skulle kunne have en sådan samfundsændrende betydning, men ikke desto mindre et det blevet til en iboende del af sociologiens selvforståelse.

Denne samtidsdiagnostiske tendens i sociologien er fortsat op i nutiden, og de senere år har bragt flere samtidsdiagnoser på banen og introduceret nye begreber, hvormed karakteren af samfundet kan bestemmes. Blandt disse er bl.a. stadig mere udbredte begreber som 'prekariat' og 'prekarisering'. Det er ikke for meget at hævde, at der i de senere år er opstået en mindre hype omkring brugen af dem i forskellige sociologiske analyser. Denne hype skyldes delvis den samfundsvidenskabelige gennemslagskraft, som disse begreber har haft, og dels den politiske bevågenhed, som de har tiltrukket sig. 'Prekarisering' og 'prekariat' er i udgangspunktet ikke særligt mundrette begreber på dansk, men det stammer fra det franske 'precarité' og det engelske 'precariousness'. Indholdsmæssigt henviser de til - og bidrager til at indfange - en tilsyneladende ny form for usikkerhed, der karakteriserer nutidens samfund i almindelighed og arbejdsmarked og arbejdsliv i særdeleshed, ligesom de anvendes til at begrebsliggøre opkomsten af en helt ny klasse. Meget kort fortalt kan 'prekarisering' bedst forstås som en mangesidet proces, hvis udgangspunkt såvel som afledte konsekvenser i sig selv er usikkerhed, og som aflejrer sig i - og etablerer forudsætningerne for - opkomsten af en ny klasse af 'prekære' mennesker. Således rammer begreberne ned i nogle af sociologiens primære genstandsfelter, hvilket kun bidrager til, at de vækker så stor genklang.

Men inden vi forføres til at sluge disse begreber og deres medfølgende samtidsdiagnostiske analyser råt, er det efter vores mening væsentligt at rejse nogle centrale 
spørgsmål. Det er jo som nævnt langt fra første gang, at sociologer kritisk dissekerer, diagnosticerer og tilbyder farverige begreber til at beskrive tingenes tilstand i relation til arbejdslivet. Så vi må derfor stille os det spørgsmål, om prekariserings- og prekariatsbegreberne reelt bidrager med noget nyt? Bliver vi klogere af at benytte den analytik, som de anlægger, og gør den os bedre til at bestemme karakteren af vores samfund? Eller er prekarisering blot endnu en slags 'bulldozerbegreb' (Illouz 2008), der udjævner alt på sin fremfærd, og som gør os lidt sneblinde over for andre mulige vinkler på en samfundsmæssig udvikling? Det vil vi i denne artikel forsøge at belyse og diskutere nærmere. Fremgangsmåden i det følgende er, at vi først gennemgår tre nyere sociologiske samtidsdiagnoser over tilstanden i nutidens arbejdsliv: (1) fleksibiliseringsdiagnosen (Richard Sennett), (2) brasilianiserings/balkaniseringsdiagnosen (Ulrich Beck/Zygmunt Bauman), og (3) kommercialiseringsdiagnosen (Arlie R. Hochschild) for dernæst at knytte disse tre diagnoser til et af de seneste skud på stammen: (4) prekariseringsdiagnosen (Guy Standing). Artiklen rejser således spørgsmålet, som vi vender tilbage til afslutningsvis, hvorvidt der med prekariseringsbegrebet reelt er noget nyt under solen, om det blot er udtryk for en vis sociologisk amnesi, en i disciplinen iboende modernitetsnostalgi eller et ønske om at promovere sin nye sociologiske samtidsdiagnose ved at genopdage/genopfinde gammelkendte problemstillinger.

\section{Fleksibiliseringsdiagnosen - udhulingen af personligheden}

Som nævnt i indledningen, så er prekarisering en proces, der involverer mange forskellige, men ikke desto mindre indbyrdes relaterede, udviklingstræk, og som påvirker mange forskellige sfærer af samfunds- livet. Prekarisering er således ikke blot ét fænomen, men derimod et udtryk for en kombination af flere forskellige, men ofte gensidigt forstærkende udviklingstræk, der særligt op igennem de forgangne årtier med stadig større gennemslagskraft er slået igennem særligt inden for arbejdslivssfæren. En af dem, der måske mest prægnant har beskrevet fremvæksten af prekariseringstendensen (allerede inden begrebet for alvor blev anvendt) inden for arbejdslivet, er den amerikanske sociolog Richard Sennett. Sennetts forfatterskab er ganske omfattende og bredtfavnende, men i denne sammenhæng er det særligt én af hans bøger, Det fleksible menneske (1998/1999), der tilbyder et kritisk perspektiv på arbejdslivets forvandling inden for dét, han betegner som nutidens 'fleksible kapitalisme'. Der findes dog allerede i bogen The Hidden Injuries of Class (Sennett \& Cobb 1972) kim til en kritisk analyse af særligt middelklassens stadig mere intensiverede kamp for anerkendelse, og ligeledes bidrager hans bog The Fall of Public Man (1992) med en forfaldsfortælling om den offentlige sfæres skæbne i det amerikanske samfund og af en tiltagende følelse af ensomhed og isolation. De væsentligste bidrag til en forståelse af nutidens arbejdsliv, dets grundlag og konsekvenser, er som nævnt imidlertid at finde i Det fleksible menneske, men også senere i Respect (2003) berører Sennett, hvordan den stadig mere åbenlyse afvikling af det kollektive ansvar for hinanden skaber grobund for usikkerhed og dermed for nødvendigheden af på ny at adressere og analysere de former for ulighed, uværdighed og disrespekt, der følger i kølvandet på den fleksible kapitalismes fremvækst.

Det centrale ved Sennetts beskrivelse af den fleksible kapitalismes fremvækst er således, at den er et udtryk for, at den sikkerhed og de faste former, der kendetegnede fortidens mindre fleksible kapitalisme, nu 
efterhånden er en saga blot. Den fleksibilitet, som den fleksible kapitalisme i dag er funderet på, er ikke blot et krav, som skal honoreres af arbejdstagerne - den er blevet et decideret grundvilkår for det arbejdsliv, man nu og fremover skal forvente at kunne fungere på. Fleksibilitet er måske et begreb, som vi intuitivt forbinder med noget positivt, men hos Sennett handler det imidlertid ikke blot om, hvad man som medarbejder selv gør eller kan gøre i ens arbejdsliv, men også om, hvordan omskiftelige ydre forhold konstant presser mennesker til at bøje sig efter den fleksible kapitalismes behov og krav (Sennett 1998/1999:47). Omlægninger, rationaliseringer, reduktioner, udflytninger og nedlæggelser er nu en forventelig del af mange virksomheders stadig mere globaliserede virkelighed, og ifølge Sennett smitter dette også af på mulighederne for at opbygge en karriere og på skabe et arbejdsliv. Fortidens åbenlyse kontrol, tvang og bureaukrati pakkes nu ind i floromvundne og besnærende men ikke desto mindre bedrageriske strategier, der lægger et røgslør ud over det faktum, at frihed faktisk blot er et udtryk for usikkerhed, og at magten nu bare udøves på nye og mere subtile måder:

"Fleksibiliteten bruges $i$ dag som endnu en måde at befri kapitalismen for undertrykkende konnotationer på. Ved at nedbryde det stivnede bureaukrati og fremhoeve risikoen giver fleksibiliteten - hoevder man - folk mere frihed til selv at forme deres liv. I realiteten indfører den ny orden nye kontrolformer ... men disse nye kontrolformer er svaere at få øje på. Den nye kapitalisme er ofte proeget af uigennemskuelig magtudøvelse" (Sennett 1998/1999:8).

Et andet vigtigt element af fleksibiliseringsdiagnosen er, at den ikke blot påpeger, hvordan de ydre rammer for arbejdslivet nu er forandrede, men også hvordan den indre oplevelse af arbejdet er blevet forvandlet under den fleksible kapitalisme.

I Det fleksible menneske genbesøger Sennett små tre årtier senere en af sine tidligere informanter, Enrico, fra The Hidden Injuries of Class. Fortællingen om den italienske andengenerationsindvandrer Enrico, der er fagforeningsansat vicevært, og hans søn Rico, der er en succesfuld teknologi-ingeniør, bærer vidnesbyrd om den tiltagende fragmentering og udtæring af personligheden og det øgede pres for at være villig til at ofre alt for en uforudsigelig karriere, som den fleksible kapitalisme medfører. Hvor en karriere tidligere betød en trinvis opstigen af en på forhånd fastlagt udviklingstrappe, så smuldrer trinnene nu øjeblikkeligt under fødderne på dem, der betræder trappen. Fortidens rutineprægede og monotone arbejdsopgaver, som faderen Enricos arbejde har bestået af, kan måske fornedre og fremmedgøre, som Sennett så rigtigt bemærker, men de kan også skabe et sikkert og trygt fundament under et arbejdsliv, hvorimod sønnen Ricos konstante karriereskift og kamp for at holde sig i fronten af feltet vidner om, hvordan forholdet mellem livserfaring, kontrol med tiden og karakterdannelse, der tidligere hang så nøje sammen, nu er splintret i småstykker (Sennett 1998/1999:43-44). Konstant forandringsparathed og omskiftelige livsprojekter har erstattet bureaukrati og blind rutine. I tillæg hertil bevirker den gradvise underminering af fagforeningerne og af den kollektive kamp for forbedringer af arbejdsforhold, at denne kamp nu må kæmpes alene, og at man i sidste instans kun har sig selv at takke for både sejre og nederlag. ${ }^{.}$Sennett skriver således afslutningsvis i sin bog på baggrund af sine iagttagelser ved det årlige møde i den schweiziske by Davos mellem verdens førende økonomiske ledere, at dis- 
se, den fleksible kapitalismes nye bannerførere, godt ved, at

"den fleksibilitet, de bekender sig til, ikke giver nogen retningslinjer for, hvordan man lever et almindeligt liv. De nye herrer har forkastet karrieren i den gamle almensproglige betydning af ordet - som stier, folk kan følge livet igennem. Stier af varig og konstant handling er for dem fremmed territorium" (Sennett 1998/1999:166).

Sennetts bidrag til prekariseringstesen skal således ses i hans understregning af, hvorledes den fleksible kapitalisme i stigende grad udhuler menneskers personlighed, afkobler kontinuiteten mellem fortid, nutid og fremtid og rokker ved deres livsfundament, og hvordan kravet om fleksibilisering skaber en dybtliggende følelse af utilstrækkelighed og uforudsigelighed hos dem, der skal forsøge at finde og opretholde mening med deres arbejde.

\section{Brasilianiserings- og balkaniseringsdiagnosen - risikosamfundets bundfældelse $\mathbf{i}$ arbejdslivet}

En anden indirekte sociologisk forløber for den nu stadig mere italesatte prekariseringsdiagnose udgøres af den tyske sociolog Ulrich Beck, der med sin tese om 'risikosamfundet' (Beck 1986/1997), som senere kobledes mere specifikt til nutidens arbejdsmarked (Beck 1999/2002), har indfanget den tiltagende betydning, som risicioplevelser og risicikonstruktioner har både i menneskers liv og i samfundets funktionsmåde. Det er Becks grundpointe, at risikosamfundet i det 'andet moderne' er vokset frem på skuldrene af det 'første modernes' industrielle klassesamfund, og at fokus nu flyttes fra fremskridt, velstands- og vækstskabelse samt fordelingspolitiske dagsorde- ner til en udpræget opmærksomhed mod de menneskeskabte kilder til forurening, miljøproblematikker og ikke mindst den frygt og de 'farefællesskaber', som disse afføder. Risikosamfundet udfordrer imidlertid klassesamfundet, fordi klasser - ligesom mange andre klassiske sociologiske kategorier så som familie, køn og nation - nu bliver en såkaldt 'zombiekategori' (Beck \& Beck-Gernsheim 2001:202ff). Hermed menes, at klassebegrebet ifølge Beck er blevet en betegner, der har mistet det objekt, som det skulle indfange, alt mens det stadig vandrer rundt mellem de levende og præger både politiske dagsordener og sociologiske perspektiver. Selvom det fasttømrede klassesamfund, som man kendte det fra den industrielle tidsalder, måske på mange måder nu er en saga blot (og ikke mindst fordi en såkaldt 'elevatoreffekt' i den vestlige verden med tiden har løftet socialklasserne flere etager op), så er der dog ingen tvivl om, at social stratifikation stadig findes, og at arbejdslivet udgør en af de væsentligste arenaer, hvor sådanne sociale forskelle udkrystalliseres. Beck beskriver i bogen Fagre nye arbejdsverden (1999/2002), hvordan illusionen om fuld beskæftigelse - en drøm fra det 'første moderne' - nu er bristet, og at en konsekvens heraf er, at vi må anerkende, at arbejdsmarkedet i stigende grad bliver en kampplads, hvor der kæmpes om de stadig færre og stadig mere usikre jobmuligheder, der nu er tilgængelige. Beck taler om, at vi kommer til at 'McJobbe' eller arbejde på 'brasiliansk' - en metafor for, hvorledes fortidens kontinuerlige og sammenhængende arbejdsliv nu erstattes af korttidsansættelser, usikre karriereveje og en generel mangel på faste stillinger (en situation, som man har kendt det fra det brasilianske samfund). Han konstaterer, at "brasilianiseringen af Vesten er den utilsigtede konsekvens af den neoliberale utopi om det frie marked" (Beck 1999/2002:7). Han kalder også 
dette fænomen for en 'nedadgående elevatoreffekt' eller 'nedstigningen til det prekære', der ganske vist ikke rammer alle lige hårdt (og ifølge ham faktisk mænd hårdest), men som alligevel sætter rammen for mange menneskers møde med arbejdsmarkedet (Beck 1999/2002:108). Han skriver om opkomsten og konsekvenserne af denne 'brasilianisering':

\section{"Risikoregimets brasilianske version viser sig $i$ de radikale transformationer af arbejdet, der under påvirkning af den tiltagende glo- balisering siden 1980'erne og mere intensivt op gennem 1990'erne har aflokaliseret pro- duktionsformerne og åbnet arbejdsmarkedet for usikkerhedens politiske økonomi" (Beck 1999/2002:112).}

Becks bidrag til en forståelse af den fremvoksende prekarisering er således en bidende kritik af både den politiske og økonomiske udviklingstendens ('neoliberalismen'), der understøtter fremvæksten af disse 'brasilianske' tilstande. Det er imidlertid ikke kun dem, der befinder sig på arbejdsmarkedet, der oplever nye former for risici og usikkerhed, for samtidig hermed synes selve muligheden for overhovedet at komme ind på arbejdsmarkedet stadig mere begrænset. Becks diagnose, ligesom Sennetts, er således en særdeles dyster beskrivelse af de stadig mere usikre og uforudsigelige vilkår, som arbejdslivet er karakteriseret af for store grupper af mennesker. Risikosamfundets problemer siver ned på individniveau. Mennesket må, ifølge Beck, derfor i stigende grad søge efter livsbiografiske løsninger på sådanne systemiske modsætninger (Beck 1986/1997:218), og eftersom dette er en nærmest umulig opgave, der kun sjældent reelt forandrer de grundlæggende strukturelle og systemiske modsætningsforhold, så argumenterer Beck for skabelsen af et kosmopolitisk medborgerskab (borger- rettigheder, borgerarbejde og borgerløn), der skal udgøre en mere effektiv og handlekraftig modmagt til dette nu efterhånden globalt forankrede arbejdssamfund (Beck 2002/2006).

Ligesom Beck mener også den polskengelske sociolog Zygmunt Bauman, at arbejdsmarkedet og arbejdslivet i dag er kendetegnet ved opbrud og en historisk hidtil uset grad af usikkerhed, og han bidrager således, ligesom Beck, både til den føromtalte fleksibiliseringsdiagnose og til brasilianiserings/balkaniseringsdiagnosen. Bauman har gennem adskillige år interesseret sig for arbejdet og arbejderklassen som sociologisk tema (se f.eks. Bauman 1972, 1982), og i de senere har han, som Beck, knyttet denne interesse an til en mere generel kritisk samtidsdiagnose om overgangen fra én modernitetsform til en anden. Når Bauman skal beskrive nutidens situation, så vender han sig begrebsligt dog snarere mod Balkan end Brasilien - om end resultatet stort set er det samme. Bauman taler om, at nutidens 'flydende moderne verden' er blevet 'balkaniseret'. Hermed mener han, at den sammenhæng og forudsigelighed, der prægede dét, han kalder for den 'faste modernitet' og med den fortidens 'tunge kapitalisme' i nutidens 'flydende modernitet' med dens 'lette kapitalisme', er blevet fragmenteret og opsplittet i en mangfoldighed af gennemindividualiserede, indbyrdes konkurrerende og usammenhængende livsprojekter - ligesom fragmenteringen af Balkanhalvøen op gennem 1990'erne (Bauman 2000/2006). Der er ikke længere én stor vision for eller utopi om 'det gode samfund'. Som en konsekvens heraf er livet - og ligeledes arbejdslivet - for mange blevet til et kludetæppe af drømme, ambitioner og projekter uden nogen nødvendig indre sammenhæng eller fælles retning. Arbejdspladsen opfattes i dag ifølge Bauman snarere som en campingplads, hvor man for en kort tid slår 
lejr, men ikke som en livsprojekt præget af loyalitet og gensidig tillid. Bauman konstaterer, at selvom arbejdslivet nok altid har været præget af usikkerhed, så er nutidens usikkerhed mangesidig og med årsager og konsekvenser, som den enkelte vanskeligt kan håndtere. Den usikkerhed, som Bauman beskriver, handler - ligesom hos Beck - derfor ikke kun om at kunne få fodfæste på et stadig mere konkurrencepræget arbejdsmarked, men også, som hos Sennett, om at kunne skabe en sammenhængende, forudsigelig og meningsfuld tilværelse. Han skriver: "Sikre job på sikre virksomheder synes at voere det stof, bedsteforoeldrenes nostalgi er giort af" (Bauman 2000/2006:208). Som Bauman ligeledes bemærker: hvis man tidligere blev ansat som lærling på Fordfabrikken, så kunne man også med ret stor sandsynlighed se frem til at blive pensioneret fra samme sted mange årtier senere (Bauman 2004:60). Sådan er det ikke længere. Varigheden af ansættelser - ligesom varigheden af alt andet (parforhold, karriereplaner osv.) - er nu stærkt begrænset. Baumans analyse af den såkaldte 'flydende modernitet' indikerer altså, at alt det, der tidligere var fast, forudsigeligt og forbundet med stabilitet, tilknytning og varighed, i dag er afløst af konstant foranderlighed og en gnavende fornemmelse af, at spillets regler hele tiden ændres, mens det er i gang. Om dette gælder for alle, kan man måske sætte spørgsmålstegn ved. For selvom den udviklingstendens, som Bauman analyserer, afspejler et generelt forhold, så rammer den nok nogen grupper på arbejdsmarkedet hårdere end andre. Ikke alle er lige udsatte for den flydende modernitets evindelige omskiftelighed, men flere og flere mærker dens konsekvenser. Dette gælder også i Danmark og i resten af de nordiske lande, hvor det flydende i stigende grad synes at underminere enhver form for fasthed (se f.eks. Petersen 2016). Og hvad gælder de yngre generationer, så synes fasthed at være en by i Rusland for dem. De kan ikke nære forhåbninger om, at arbejdsmarkedet tilbyder dem faste ansættelsesforhold. Som arbejdsmarkedsforsker Janne Glerup har udtalt til Berlingske:

\section{"Vi kan se, at arbejdsmarkedet vil blive mere usikkert. De unge, der skal ud på arbejdsmar- kedet $i$ fremtiden, vil møde langt flere mid- lertidige og løse ansaettelser. De skal kunne rumme at have en usikker indkomst og dårli- gere arbejdsbetingelser, end vi har voeret vant til" (Glerup i Hesseldal 2016).}

Fremtiden tegner med andre ord til at stå i det flydendes tegn, og det gælder åbenbart bare om at vænne sig til tanken.

Derudover hævder Bauman også, at hvor menneskers relation til samfundet $i$ almindelighed og arbejdsmarkedet i særdeleshed - og ikke mindst deres selvidentitet - i den faste modernitet knyttede an til ens producentrolle (man var, hvad man lavede), så udviklede den sig gradvis i den flydende modernitet til at være en forbrugerrolle (man er nu dét, man forbruger). Denne forandring har bevirket, at man er gået fra et samfund, hvor samfundet stillede krav til det enkelte individ om at indordne sig arbejdsforholdene og bidrage til det fælles bedste, til en ny samfundsformation, hvor den enkelte nu stiller krav til samfundet om at tilbyde, give råderum for og understøtte de individuelle livsprojekter. Som Bauman skriver:

"Arbejdet [har] - i lighed med andre livsaktiviteter - $i$ det store og hele fået en aestetisk betydning. Det skal voere tilfredsstillende i sig selv og ikke vurderes $i$ forhold til de faktiske eller formodede virkninger, det måtte have på menneskelige medsøstre eller -brødre, på nationers eller landets ve og vel, endsige på 
fremtidige generationers lykke" (Bauman 2000/2006:181).

Bauman begræder den udvikling, som det flydende moderne arbejdsliv har undergået. Han er af den opfattelse, at med den tiltagende brasilianisering og balkanisering af både samfund og arbejdsliv følger en større grad af uforudsigelighed og en mangel på indre sammenhængskraft og solidaritet, der som en endemisk tilstand vil brede sig ikke kun blandt dem, der for nuværende har et arbejde, men også til dem, der ikke har og ikke mindst til dem, der permanent står udenfor. Bauman mener derfor, at denne udvikling også skaber grobund for fremvæksten af en gruppe af 'nye fattige' og 'defekte forbrugere' (Bauman 1998/2002) eller såkaldt 'forspildte liv' - mennesker, der ikke har nogen værdi eller funktion i vores samfund, og som i modsætning til fortidens arbejdsløse nu ikke har udsigt til på et tidspunkt at blive forløst fra deres marginalisering og geninddraget i samfundet (Bauman 2004/2005). Baumans samtidsdiagnose af arbejdslivet hviler således på en skarp kritik af den tiltagende afmontering af velfærdsstaten og den politiske deregulering, af de ubønhørlige globaliserings-, privatiseringsog individualiseringstendenser, af det stadig mere stratificerede forbrugersamfund og ikke mindst af de menneskelige konsekvenser, som disse forskellige, men ikke desto mindre gensidigt understøttende, udviklingstræk medfører.

\section{Kommercialiseringsdiagnosen - når markedskulturen koloniserer familielivet $^{2}$}

Den amerikanske sociolog Arlie Russell Hochschild er en af pionererne inden for udviklingen af den feministisk- og interaktionistisk-inspirerede kritiske følelsessociologi, og hun har gennem en menneskeal- der beskæftiget sig med, hvordan følelser i stigende grad kommercialiseres og gøres til et produktivt anliggende i det moderne arbejdsliv. På den måde aktualiserer hendes arbejde, hvordan følelser $i$ arbejdslivet er blevet et stadig mere udbredt tema inden for samfundsforskningen (Fisher \& Ashkanasy 2000). Hochschilds mest berømte værker er nok The Managed Heart (1983) og The Time Bind (1997/2003) - som begge efterhånden kan siges at være sociologiske klassikere. Begge disse bøger viser på hver deres måde, hvorledes ægte følelser i arbejdslivssituationer erstattes af indstuderede og overfladiske 'følelsesfremvisninger' (emotion displays), og hvordan mennesker i stigende grad oplever et stadig større krydspres mellem forventningerne til karrieren og mulighederne for at skabe et meningsfuldt familieliv. Den bog, vi her skal fokusere på, er imidlertid en anden og nyere, nemlig The Commercialization of Intimate Life (2003). Heri viser Hochschild gennem et righoldigt kildemateriale, hvordan nutidens følelseskultur i stigende grad kommercialiseres og gennemsyres af en kapitalistisk forbrugstankegang. Allerede i bogens titel tydeliggøres det, at dét, der er på spil, er en kritisk kommentar til kommercialiseringen af menneskelige relationer, som følger i kølvandet på den globale kapitalismes stadig mere omsiggribende karakter. Med 'kommercialisering' henviser Hochschild således til, hvorledes dét, der ellers i udgangspunktet ikke er omfattet af pengeøkonomien - så som menneskelige følelser, familieliv og intimitet - i stadig stigende grad gøres nytte- og profitorienteret. Bogen indledes med en konstatering af, at følelsesarbejde som en del af kapitalismens udvikling i stigende grad uddelegeres og udliciteres. Hochschild stiller således indledningsvis spørgsmålet:

"Når vi supplerer eller erstatter familie-baseret omsorg med betalt omsorg, hvordan får 
$v i$ det så til at fungere på en menneskeligt meningsfuld måde?" (Hochschild 2003:2).

Svaret på spørgsmålet er, at vi tilsyneladende lærer at leve med, at omsorgen, nærheden og intimiteten kommercialiseres og udliciteres ligesom alt andet i samfundet. I bogen viser Hochschild bl.a., hvordan fænomenet 'betalt omsorg' er blevet en stadig mere udbredt og accepteret del af det amerikanske samfund, og hvordan dét, der tidligere blev betragtet som naturlige og frivillige opgaver, som blev varetaget af familien eller fællesskabet uden betaling, nu i stigende grad uddelegeres eller udliciteres til 'specialister' - opgaver så som børnepasning, ældreomsorg, hospicearbejde, lejrskoleture og (særligt for de mere velstillede) arbejdsopgaver, der varetages af chauffører, au pairs, fødselsdagskoordinatorer, bryllupsarrangører eller opgaven med at skrive takkekort eller samle og katalogisere familiebilleder. Meget af det arbejde, som nu udliciteres til andre, er netop det følelsesarbejde, som traditionelt kvinder har forestået. Derfor er Hochschilds analyse også særligt optaget af kvinders situation, om end hun også kommenterer på kommercialiseringens indvirkning på mænds følelsesliv og karrieresituation.

Lad os tage et par nedslag i nogle af de interessante essayistiske analyser fra The Commercialization of Intimate Life (2003), der illustrerer kommercialiseringstendensens kraftigt omsiggribende karakter. På baggrund af studier af selvhjælpsbøger ('advice books') til kvinder over de seneste årtier viser Hochschild eksempelvis, hvordan kvinder i nutidens kapitalisme befinder sig $i$ et konstant krydspres mellem på den ene side at forvente for meget af kærligheden og intimiteten og på den anden side at være en del af en kultur, hvor kvinder i stigende grad underlægges maskuline 'kærlighedsregler'. Denne tendens afspejles i selvhjælpsbø- gernes råd til kvinder om at adskille kærlighed fra sex, at vente med at forelske sig indtil karrieren er på plads, eller at det er okay for gifte kvinder at have lejlighedsvise sidespring (Hochschild 2003:27). For at få hjælp til at navigere i dette krydspres konsulterer en del kvinder råd fra en række 'eksperter', der har skrevet forskellige selvhjælpsbøger. Forfatterne til selvhjælpsbøger for kvinder betegnes af Hochschild f.eks. som 'emotionelle investeringsrådgivere', fordi de - lige som økonomiske rådgivere - fortæller, hvordan kvinder mest optimalt skal fordele deres følelsesmæssige opmærksomhed mellem mand, børn, arbejdsplads og egne personlige behov (Hochschild 2003:14). Hochschild detekterer tilstedeværelsen af en såkaldt 'kulturel afkøling' i disse selvhjælpsbøger, som kommer til udtryk ved, at kvinder i forhold til tidligere nu både forventes at være i stand til at håndtere åbne og ligeværdige relationer til mænd (en paradoksal konsekvens af feminismens sejrsgang), samtidig med at kvinderne også samtidig skal være mindre følsomme og anvende køligere følelsesmæssige strategier i deres relationer. Det vigtige bliver altså ikke at føle mindre, men at håndtere sine følelser bedre. Disse selvhjælpsbøger fortæller også læseren, hvordan de 'bør' føle i stedet for at lade sådanne følelser være spontane, intuitive eller naturlige, hvilket blot bidrager til en yderligere distancering fra kvinders naturlige følelser og skaber en følelse af fremmedgørelse fra kvinders følelsesliv.

I bogen er Hochschild desuden også optaget af at begrebsliggøre og diskutere de forskellige måder, hvorpå 'omsorg' ('care') kommer til udtryk i nutidens følelsesmæssigt afkølede kapitalisme. Hun sondrer mellem den 'traditionelle patriarkalske model' med en hjemmegående husmoder, den 'postmoderne forvrængede model' med den hårdtarbejdende supermor som omdrejningspunkt, den 'kolde moderne 
model' med dens upersonlige institutionaliserede omsorg, og slutteligt den 'varme moderne model', hvor både mænd og kvinder på ligeværdig vis varetager omsorgsopgaver i samarbejde med institutioner. Dét, der kendetegner nutidens amerikanske samfund - i modsætning til eksempelvis de nordiske lande - er, at der er ved at opstå en uhensigtsmæssig syntese mellem den postmoderne forvrængede model og den kolde moderne model, hvilket Hochschild betegner som en 'omsorgens krise' (Hochschild 2003:213ff). En af konsekvenserne af denne tiltagende kommercialisering af familie- og følelseslivet, som kommer til udtryk i forskellige sammenhænge, er, at "den baner vejen for et mistillidsparadigme" (Hochschild 2003:24), der adskiller i stedet for at forene; et paradigme, der ikke bare er overfladisk, men som også drives frem af en ånd af 'instrumentel distance'. Konsekvenserne af denne udvikling, hvor vi på forskellig måde udliciterer følelses- og omsorgsarbejde til andre, er dog ikke nødvendigvis udelukkende negative - det betyder også, at vi har mulighed for at bruge vores tid på andre og måske mere interessante opgaver, men samtidig mister vi en stor del af følingen med de personlige relationer, vi indgår i (Hochschild 2003:3). På den måde er kapitalismens nye afkølede følelseskultur et tveægget sværd. I et interview har Hochschild fortalt om, at dét, hun forsøgte at vise i bogen, var det hun kalder for 'kapitalismens paradoks':

"Vi er $i$ dag fanget $i$ det, jeg vil betegne som kapitalismens paradoks. På den ene side havde amerikanerne behov for det. 19. og 20. århundredes kapitalisme - et robust og dynamisk produktions- og forbrugssystem for at kunne forlange det af livet, som vi nu gør ... På den anden side er kapitalismen - og dens forbrugsimpuls - begyndt at absorbere de selvsamme impulser, som den forst satte fri. Vi bliver nødt til at granske historien nøje for at få øje på dette paradoks" (Hochschild i Wilson \& Lande 2005:278).

Dette paradoks består i, at kapitalismen både har skabt grobund for positive tendenser som frisættelse, foretagsomhed og udbredt kønsligestilling, men samtidig udhuler den også vores følelsesliv og tømmer det for mening. Man kan således skimte konturerne af Jürgen Habermas' (1987) klassiske koloniseringstese i Hochschilds kommercialiseringsdiagnose. Når intimiteten kommodificeres og kommercialiseres, så mister mennesker - og i Hochschilds optik måske særligt kvinderne, der, med hendes velvalgte ord, er "sprunget fra patriarkiets stegepande og lukt ind i kapitalismens flammer" (Hochschild 2003:148) - en grundlæggende indføling med livet, for kapitalismens flammer viser sig ikke at være varme, men derimod kolde. For at modvirke denne tendens foreslår Hochschild, at vi igen må forsøge følelsesmæssigt at opvarme den i stigende grad afkølede globale kapitalisme, og specifikt argumenterer hun for "mænds deltagelse i arbejdsopgaver i hjemmet, familievenlige politikker på arbejdspladsen og en social værdsættelse af omsorgsopgaver" (Hochschild 2003:270).

Ligesom i mange af Hochschilds andre bøger, så skriver hun således mulige udveje fra kommercialiseringstendensen ind i sine analyser. I den sammenhæng er arbejdet altid essentielt. Hendes omdrejningspunkt er, hvordan følelser skal/bør engageres i arbejdet (Hochschild 1983); hvordan arbejdet sluger stadig mere af vores tid, og dermed tager tid væk fra vores familieliv (Hochschild 1997/2003), men som vi dog kan forsøge at overkomme og modvirke gennem forskellige mere eller mindre effektive håndteringsstrategier (Hochschild 2004), eller som i dette tilfælde, hvorledes arbejdet antager forskelligartet karakter for 
mænd og kvinder - og dermed skævvrider forholdet imellem kønnene - inden for rammerne af en stigende kommercialisering af tilværelsen. Arbejdet som fænomen, og således de ændrede betingelser for vores arbejdsliv i en moderne kapitalistisk verden, er dermed i centrum for hendes analyser af kommercialiseringen af tilværelsen i almindelighed og arbejdslivet i særdeleshed.

\section{Prekariseringsdiagnosen - usikkerhed som udgangspunkt for social udstødelse}

Tanken om kapitalismens følelsesudbyttende og relationsfortyndende karakter, der på mange måder gennemsyrer samtlige Hochschilds værker - og som løber som en rød tråd gennem hele kommercialiseringsdiagnosen - antager en noget anderledes karakter, når det drejer sig om analysen af prekariatets opkomst. For at få analytisk greb om dette fænomen, er det først og fremmest væsentligt at adskille 'prekariatet' (forstået som en ny klasseformation) fra forestillingen om 'prekarisering' (som en samfundsmæssig udviklingstendens). Hvad angår sidstnævnte, så er det nærmest sociologisk 'comme il faut' at karakterisere vores samtid (og i og for sig enhver samtid, som sociologer skriver i) som værende gennemsyret af prekarisering eller en tiltagende usikkerhedsfølelse. Her refereres ofte til en samfundsmæssig situation præget af strukturelt opbrud og nedbrud, hvor (ud)flydende sociale regler og normer florerer, der sætter sig igennem i form af problematiske selvforhold, som skaber betingelserne for nye fremmedgørelsestyper (Rosa 2014), og som bl.a. baner vejen for psykologiske patologier som eksempel angst (Sennett 2006) og depression (Petersen 2016). Prekariseringen aflejrer sig således på forskellige måder og etablerer måske endda betingelserne for fremvæksten af en helt ny klasse af mennesker - prekariatet. Det er i hvert fald den engelske økonom Guy Standings påstand, og selvom han i dag i vid udstrækning nærmest personificerer prekariseringsdiagnosen, så bør man dog huske på, at også andre fremtrædende sociologer allerede en del år tidligere italesatte prekariseringsbegrebet som f.eks. hos Pierre Bourdieu (1998) med betoningen af 'précarité' som et særligt samtidsfænomen, hos Zygmunt Bauman (1999) med formuleringen af 'Unsicherheit' som et trehovedet uhyre i den flydende modernitet bestående af henholdsvis utryghed, usikkerhed og uvished, hos Judith Butler i bogen Precarious Life (2004) og i Isabell Loreys seneste bog State of Insecurity: Government of the Precarious (2015). Der er således ingen tvivl om, at prekariseringsbegrebet godt og grundigt har fanget den sociologiske fantasi særligt i det nye årtusinde, men faktisk stammer prekariseringsbegrebet helt tilbage til 1970'erne, hvor det inden for fransk økonomi og sociologi blev anvendt til at beskrive familiers fattigdomsudsathed i relation til den høje arbejdsløshedssituation, og det var først senere, at det specifikt blev knyttet til menneskers stadig mere usikre ansættelsesforhold (Barbier 2002:5-6), som vi f.eks. ser det både inden for fleksibiliseringsdiagnosen og balkaniseringsdiagnosen - og senest også hos Guy Standing.

I The Precariat: The New Dangerous Class, fremanalyserer Standing - som titlen mere end antyder - den ulmende tilstedeværelse af en helt ny og farlig klasse (Standing 2012a). Det er åbenlyst, at den marxistiske grundfigur om 'proletariatet' har inspireret formuleringen af begrebet om 'prekariatet'. I Standings optik er prekariatet imidlertid endnu ikke at forstå som en klasse i Karl Marx forstand - altså som en klasse for sig - men derimod som en klasse, der er kraftigt under opsejling. Denne klasse består 
af et konglomerat af mennesker, hvis fællesnævner - hvis samlende karakteristika - er den af prekariseringen skabte usikkerhed. De lever fra hånden til munden; har usikre, undertrykkende og kortvarige jobs uden udsigt til sikre ansættelsesforhold; er frustrerede studerende og unge, som har mistet fornemmelsen for en bedre fremtid; kriminaliserede og brændemærkede mennesker, der ekskluderes af majoritetssamfundet; arbejdsløse mennesker, der kun kan spejde langt efter muligheden for at forsørge sig selv. Betegnelsen 'prekariat' dækker således bredt, men samles alligevel i én væsentlig konsekvens:

"De er udloendinge med permanent opholdstilladelse (denizens); de har foerre sociale, kulturelle, politiske og økonomiske rettigheder end de medborgere, de lever iblandt" (Standing 2011:1). ${ }^{3}$

Den analytiske skelnen, som Standing foretager mellem mennesker med 'opholdstilladelse', og 'medborgere', er naturligvis ret voldsom. Argumentet om, at prekariatet simpelthen ikke er indehaver af de samme rettigheder som medborgerne må Standing naturligvis underbygge. Det gør han ved at henvise til udviklingens strukturelle komponenter. Her hæfter han sig i særdeleshed ved den platform, som han mener globaliseringen hviler på. I hans forståelse konstrueres globaliseringen af uforstyrret markedsliberalisering (kapitalisme uden stopklodser), politisk deregulering og hyldesten af den konkurrerende individualisme, der alt $i$ alt har underdrejet og afviklet muligheden for, at kollektive instanser har kunnet repræsentere de udsatte og lavindkomstgruppernes interesser og dermed understøtte et velfungerende socialt sikkerhedssystem. Denne udvikling er systematisk. Altså motorerne, som har drevet denne udvikling fremad, er understøttet af magtfulde politiske og økonomiske interesser, ligesom de hviler på et stærkt moralsk fundament: idealet om, at mennesket er sin egen lykkes smed. Problemet hermed er bare, at alle ikke har mulighed for at smede sin egen lykke - dertil rejser der sig en lang række strukturelle barrierer, der forhindrer dem i det. Og ifølge Standing, så er denne udvikling pågående. Prekariatet vokser, fordi de strukturelle mulighedsbetingelser for dets formindskelse ikke understøttes - snarere tvært imod (Standing 2012b: 591).

Den proces vil Standing imidlertid gerne sætte skub i - han vil gerne bane vejen for, at prekariatet kan blive medborgere. I den forstand er hans projekt stærk politisk, hvilket kræver, at han tager dem i ed, som han taler på vegne af. Han skal, med andre ord, have tiltro til prekariatets mulighed for at vokse sig ud af dets nuværende situation. I den sammenhæng er Standing blevet kritiseret. Som en anmeldelse af Standings bog således konkluderer:

"Set i dette perspektiv, så synes Standing ikke
at have megen tillid til prekariatets evne til
at frembringe deres egen 'paradispolitik'. At
underspille prekariatets handleevne (agency)
synes at vaere den største mangelvare i dette
ellers appellerende og vigtige vaerk" (Skoc-
zylas \& Mrozowicki 2012:589).

Når man - som Standing - stikker næsen frem og forsøger at tale på vegne af nogen, så risikerer man at få smæk. Andre end Standing har mærket denne type af kritik. Karl Marx' mangeårige samarbejdspartner Friedrich Engels, i forbindelse med bogen The Condition of the Working Class in England (Engels 1845/1987), er blevet mødt af samme form for kritik. Engels' bog er ikke alene et nådesløst angreb på kapitalismens skruppelløse og brutale undertrykkelse af arbejderklassen - han understøtter også den marxistiske vision om, at arbejderklassen er 
en central drivkraft i den kommende revolution. På trods af denne overbevisning, så er bogen alligevel fyldt med passager, hvor Engels' væmmelse imod arbejderklassen og dens manglende vilje til forandring skinner tydeligt igennem. Eksempelvis beskriver Engels, hvordan mennesker fra arbejderklassen ofte er drikfældige, til tider uhumske og udannede, og at de i bund og grund ikke ved, hvad der i sidste instans er godt for dem (Engels 1845/1987). Det generer tydeligvis Engels, og det generer hans forestilling om arbejderklassens historisk givne plads.

I vores optik er der dog ingen sådanne tegn på, at Standing nedgør prekariatet. Hans ønske om forandring er oprigtigt, og derfor har han også taget kritikken til sig. Således har han skrevet et politisk charter, hvori han formulerer vejen frem for prekariatet. Som han skriver i indledningen:

"Kort fortalt er denne bog et fors $\emptyset g$ på at formulere en agenda for prekariatet, der kunne danne baggrund for en politisk bevaegelse, som ikke baserer sig på en utilitaristisk appel til majoritetsbefolkningen, men på en vision om, hvad der konstituerer et godt samfund. Bogen er dermed også, til en vis grad, et forsøg på at svare på reaktionerne til The Precariat" (Standing 2014:viii).

Hvorvidt Standing vil lykkes med sit forehavende, og om den 'farlige klasse' dermed virkelig bliver farlig, må vi vente med at se. Standing er dog selv ikke i tvivl. Han er overbevist om, at prekariatet nok skal rejse sig og revoltere imod dets vilkår. Som han skriver: "Om ikke loenge vil vi høre ekkoet fra 1968: Ça suffit!" (Standing 2014:32). Nok er nok - det har vi altså hørt før. Både som politisk parole, men også som samtidsdiagnostisk budskab fra forskelligt kritisk hold. Vi så det også hos Hochschild, Sennett, Beck og Bauman. Faktisk er samtidsdiagno- stisk sociologi karakteristisk ved, at den har forandringspotentialet indlejret i sig. Dette er ingenlunde odiøst. Når man forsøger at afdække karakteren af det samfund, vi lever i, så synes det ikke mærkeligt, at potentielle anvisninger, der peger hen mod noget andet, følger i dets kølvand. Måden, dette 'andet' så formuleres på, er naturligvis forskellig. I disse tilfælde er et centralt omdrejningspunkt forståelsen af - og derigennem spørgsmålet om at omtænke - hvad arbejdet er for noget, og hvordan arbejdslivet kan berige en større del af befolkningen.

\section{Fagre nye arbejdsliv - sociologisk nostalgi, amnesi, genopkog eller nytænkning?}

Som det fremgår af denne komprimerede gennemgang af fire nyere, ofte citerede og på mange måder nærmest uomgængelige samtidsdiagnoser over nutidens arbejdsliv - dét, vi har kaldt for henholdsvis 'fleksibiliseringsdiagnosen', 'brasilianiserings/ balkaniseringsdiagnosen', 'kommercialiseringsdiagnosen' og 'prekariseringsdiagnosen' - så har en række fremtrædende sociologer henover de seneste årtier kastet sig over arbejdslivet som en slags kritisk-analytisk koncentrat af mange af de mere generelle forandringer, der i almindelighed præger samfundet her i det, der med varierende sprogbrug kaldes for 'fleksibel kapitalisme', det 'andet moderne' eller 'flydende modernitet'. Disse diagnoser forbinder hver især arbejdslivet med mere omfattende samfundsstrukturelle forhold, som så siver ned på individniveauet og skaber en mangfoldighed af problemer i arbejdslivet, og diagnoserne beskriver med hver deres begrebsunivers og analytiske vinkling, hvordan mennesker nu i stigende grad er overladt til selv at skulle søge biografiske løsninger på systemisk skabte modsætninger. Som vi allerede var inde på indledningsvis i artik- 
len, så mente C. Wright Mills (1959/2002) netop, at det kun er ved at forbinde menneskers livsbiografiske oplevelser (herunder i arbejdslivet) med de omkringliggende strukturelle forhold, at vi både kan gøre os forhåbninger om at forstå og ikke mindst arbejde hen imod en løsning på samfundets problemer. En forståelse af og en løsning på samfundets problemer findes derimod ikke ved at adskille menneskers livsbiografiske oplevelser fra de omkringliggende strukturelle forhold.

De fire gennemgåede samtidsdiagnoser tilbyder alle ganske vist analytisk elegante, avancerede, tankevækkende og skarpsindige angivelser af, hvordan mikro og makro netop mødes i og udspiller sig på arbejdslivets mesoniveau. Vi må dog nok, set i lyset af de fire ovenstående diagnoser, konstatere, at der ikke er mange af dem, der foreslår reelle eller konkrete løsninger på de problemer, der påpeges. De hænger alle, på hver deres måde, fast i en forfaldsfortælling om en storslået fortid, der nu er kulmineret i en begrædelig nutid, og som ikke levner meget håb for en lykkelig fremtid. Det er, måske lige med undtagelse af prekariseringsdiagnosen, således en ret negativ dialektik, der lanceres uden en egentlig forløsende syntese. Ulrich Beck medgiver det da også med sin rammende konstatering af, at "den, som i dag diagnosticerer forfald uden opbrud, er blind; og den, som taler om opbrud uden forfald, er naiv" (Beck 1999/2002:25). Måske gør disse diagnoser sig skyldig i dét, man kunne kalde for en 'pessimistisk fejlslutning', der ved at overbetone de kritiske samtidstendenser overser meget af det gode, der faktisk er sket på arbejdsmarkedet i løbet af kapitalismens nyere udvikling. For den arbejderklasse, som interesserede Karl Marx og Friedrich Engels (og hvis levevilkår sidstnævnte så indgående beskrev i den føromtalte bog The Conditions of the Working Class in England fra 1845),var der ikke håb om meget godt. Faktisk viste Engels, at den højtbesungne industrielle revolution ikke skabte bedre arbejdsvilkår for arbejderen, men derimod kulminerede den i et arbejdsliv i skyggen af det, poeten William Blake berømt kaldte for de 'mørke sataniske fabrikker'. De levevilkår, som fabriksarbejderne og deres familier levede under, var ofte så kummerlige og uhumske, at de er svære at forestille sig i dag. Samtidig måtte den 'reservearmé' af arbejdsløse, der på daværende tidspunkt ventede på at komme ind på arbejdsmarkedet, i fraværet af en velfærdsstat, tage til takke med privat velgørenhed. Selvom disse mørke sataniske fabrikker, i det mindste i en dansk kontekst, nu i vid udstrækning er en saga blot og er erstattet af forkromede kontorbygninger af glas og beton, og selvom den private velgørenhed nu mange steder er afløst af en vidtforgrenet velfærdsstat med et historisk uset socialt sikkerhedsnet, så virker det som om, at disse ret betydelige transformationer ikke rokker meget ved den fundamentale kapitalismekritik, som denne artikels samtidsdiagnoser fremfører. Stort set alle de udviklingstendenser, der i almindelighed anses som positive (så som kvindernes indtog på arbejdsmarkedet, teknologiske fremskridt i produktionsprocessen, arbejdstidens reducering og fritidens udbredelse, arbejdsløsheds-, barsels-, sundheds-, pensions- og sygefraværsordninger, kampen mod fysisk hårdt og nedslidende arbejde og humaniseringen af mange af fortidens inhumane arbejdsformer osv.), tolkes af de beskrevne samtidsdiagnoser ensidigt i negativitetens skær eller omtales slet ikke.

Denne grænseløse pessimisme, som har præget store dele af den sociologiske arbejdslivsforskning over de seneste årtier og særligt hvis den er udarbejdet af nogle af de store generalist-sociologer som f.eks. Sennett, Beck og Bauman - har ikke meget blik for eventuelle positive udviklingstræk 
og ej heller for konkrete og konstruktive løsningsmodeller (se f.eks. Jacobsen 2004, 2007a, 2007b). Så når Richard Sennett skriver, som vi så ovenfor, at rutine kan anses som noget godt og konstruktivt, så underbetoner han samtidig også rutinearbejdets knap så attraktive sider. Når Zygmunt Bauman eksempelvis hævder, at en arbejder, der tidligere startede sin karriere på Ford-fabrikkerne, med meget stor sandsynlighed også kunne forvente at gå på pension fra det selvsamme arbejdssted, så siger det i udgangspunktet kun noget om varigheden af vedkommendes ansættelsesforhold og ikke nødvendigvis noget om de arbejdsvilkår, som arbejderen dengang blev tilbudt, eller om den glæde og motivation, som vedkommende oplevede ved sit samlebåndsarbejde. Når Ulrich Beck fremfører, at arbejdslivet $\mathrm{i}$ dag er mere risikabelt end nogensinde før, glemmer han så ikke det arbejdsliv, som industriproletariatet tidligere var dømt til at skulle leve? Eller når Arlie R. Hochschild hævder, at luften presses ud af familie- og fritidslivet af kapitalismens øgede krav om karriere og selvrealisering via arbejdet, så nedtones samtidig de åbenlyst positive og energiskabende sider ved at kunne udfolde sig gennem samt blive udfordret i og opslugt af sit arbejde. Er denne pessimisme således berettiget? Sikkert ikke, hvis vi ud fra en empirisk betragtning skal se på, hvordan meget faktisk taler for en ganske positiv udvikling for store grupper på arbejdsmarkedet i den vestlige verden. Er den virkningsfuld? Ja utvivlsomt, for det er altid lettere for sociologer at påpege - og overbevise andre om - at verden er af lave, end at hævde, at vi er på rette vej. Er den nødvendig? Helt sikkert, fordi den immervæk viser os, at der trods mange positive takter og tendenser stadig er brug for et kritisk sociologisk blik på samtiden. Spørgsmålet, der må stilles, er dog, hvorvidt de spæde skridt til at foreslå en revitalisering af fagforeningernes kollektive ansvar for arbejdstagerne (Sennett), indførelsen af borgerløn (Beck/Bauman) eller udviklingen af en personlig modstandsstrategi, hvor man vender det fortravlede karriereliv ryggen og bremser op (Hochschild), er i trit med den virkelige verden - hvor virkelige mennesker lever og arbejder - og dermed kan afhjælpe de omfattende problemer, som i nutidens kapitalisme tårner sig op foran os. De er i bedste fald utopiske og i værste fald virkningsløse, hvis formålet er grundlæggende at forandre den fremherskende kapitalistiske produktionsmåde og arbejdsetik og ikke mindst modarbejde de politisk-økonomiske tiltag, der understøtter denne. Her tilbyder Guy Standings prekariseringsdiagnose - og dens udpegning af 'prekariatet' som en potent historisk aktør - på en specifik transformativ kraft, der grundlæggende kan skabe varig forandring, men det er stadig tvivlsomt, hvorvidt dette prekariat overhovedet vil læse eller sågar blive vakt til live af et samfundsvidenskabeligt charter som Standings.

Som vi har været inde på i det ovenstående, så er der særligt foranlediget af Standings arbejde i de senere år kommet meget fokus på prekariseringsbegrebet inden for sociologien, der tilsyneladende synes at indfange en ny fremvoksende og usikkerhedspræget virkelighed særligt i relation til menneskers arbejdsliv. I det hele taget er netop usikkerhedsfølelsen blevet en iboende del af mange nyere sociologiske teoridannelser (se f.eks. Vail, Wheelock \& Hill 1999; Zinn 2008). Sociologien har altid haft sine særlige begrebslige hypes og teoretiske modefænomener, og meget tyder således på, at 'prekarisering' og påpegningen af usikkerhed blot er ét af de seneste i rækken. Allerede for mere end et halvt århundrede siden blev det imidlertid konstateret, at mange af de på daværende tidspunkt populære teorier om usikkerhedsfølelsen savnede viden- 
skabeligt belæg og mest af alt fremstod som enten kliniske betragtninger, normative vurderinger eller propagandistiske bidrag (Cameron \& McCormick 1954). Det samme spørgsmålstegn kan i lyset af ovenstående gennemgang rejses i dag. Man kan samtidig spørge sig, om ikke denne prekarisering faktisk altid har været en iboende del af det moderne arbejdsliv, og om prekariseringsdiagnosen derfor reelt bidrager med noget nyt, eller om den blot er udtryk for et sociologisk hukommelsestab og genopkog? Der er ingen tvivl om, at nutidens arbejdsliv og arbejdssamfund er rigeligt mineret med både snubletråde og lureminer, der kun ligger og venter på, at en stakkels sjæl uforvarende kommer til at træde på dem og får sit arbejdsliv forandret - måske for altid (se f.eks. Jacobsen \& Tonboe 2004; Nickelsen 2013), Men spørgsmålet om, hvorvidt prekariseringsdiagnosen reelt tilbyder noget nyt i forhold til de tre andre diagnoser, eller blot rekonceptualiserer dem, er derfor ikke lige til at besvare entydigt. Der er formentlig tale om, at fleksibiliserings-, brasilianiserings/balkaniserings- og kommercialiseringsdiagnoserne alle på hver deres måde leverer teoretisk skyts til Standings analyse, også selvom han ikke altid er lige god til at angive sin arv. Der er dog ingen tvivl om, at tesen om en tiltagende prekarisering har fat i noget vigtigt og spændende: at mange mennesker i stigende grad oplever, at deres liv er gennemsyret af usikkerhed, men også at denne følelse hviler på nogle samfundsmæssige grundvilkår, som faktisk kan forandres, såfremt man bliver bevidst herom. Som allerede Bauman konstaterede for en del år siden, så er det nemlig én ting at være fattig og udstødt $i$ et samfund, der tror på fuld beskæftigelse, fordi forhåbningen her altid lurer om, at man på et senere tidspunkt måske genindkaldes til aktiv tjeneste på arbejdsmarkedet, mens det er en ganske anden ting at være fattig og udstødt $\mathrm{i}$ et forbrugersamfund, hvor en sådan forhåbning for mange definitivt synes udslukket (Bauman 1998/2002:9). Det er denne nye og fortvivlende oplevelse, som prekariseringsdiagnosen stiller skarpt på, men som den også - gennem påpegningen af 'prekariatets' opkomst og dets potentielle mobilisering - tilbyder en mulig og radikal løsning på.

\section{Afslutning}

I denne artikel har vi ønsket at tegne konturerne af en række nyere og forskellige men indbyrdes relaterede sociologiske samfundsdiagnoser, der på hver deres måde beskriver en tiltagende grad af usikkerhed og uforudsigelighed i forhold til nutidens arbejdsliv. Disse forskellige diagnoser har vi i det foregående henholdsvis kaldt for 'fleksibiliseringsdiagnosen', 'brasilianiserings/balkaniseringsdiagnosen', 'kommercialiseringsdiagnosen' og 'prekariseringsdiagnosen', der repræsenteres af en vifte af fremtrædende nutidige sociologer og samfundsforskere så som Richard Sennett, Zygmunt Bauman, Ulrich Bech, Arlie R. Hochschild og Guy Standing. Vi har i det ovenstående kort gennemgået nogle af hovedpointerne fra hver af disse diagnoser, vel vidende at vi af pladshensyn kun har kunnet kradse lidt i overfalden på hver af dem. Formålet har særligt været at diskutere og vurdere, hvorvidt den i disse år særdeles omtalte prekariseringsdiagnose bibringer noget nyt og anderledes i forhold til de andre diagnoser, eller om den i vid udstrækning lægger sig i samme spor som disse. Vi har i den ovenstående diskussion foreslået, at prekariseringsfænomenet både trækker på og gentager nogle efterhånden klassiske kritiske forståelser fra de andre diagnoser, men at den også lægger noget nyt til: for det første i dens meget klassespecifikke perspektiv samt for det andet 
ikke mindst i dens udvikling af et decideret handlingsanvisende 'charter', der er rettet mod definitivt at gøre op med prekarisering og prekariat.

Artiklen har således vist, hvorledes tesen om prekarisering både rummer mange prægnante betragtninger og kritiske potentialer, samtidig med at vi også har diskuteret, hvorvidt prekariseringsbegrebet - som en slags sociologisk 'bulldozerbegreb' - ikke blot skubber en række efterhånden indgroede pointer foran sig og måske dermed også risikerer at tegne et for entydigt og fortegnet billede af nutidens arbejdsliv. Kritiske begreber som prekarisering og prekariat indbefatter jo ret entydigt en opfattelse af,

\section{Noter}

1 Det kan altid diskuteres, om denne udviklingstendens også kan siges at gælde for det dansk/nordiske arbejdsmarked og arbejdsliv. I vores optik berører Sennetts analyser af den amerikanske virkelighed væsentlige elementer, som også kan genfindes - om end, indtil videre, i mindre udpræget form - i danske og nordiske forhold.

\section{REFERENCER}

Barbier, Jean-Claude (2002): A Survey of the Use of the Term Précarité in French Economicsand Sociology. Arbejdspapir nr. 19 fra CNRS/Centre d'études de l'emploi.

Bauman, Zygmunt (1972): Between Class and Elite - The Evolution of the British Labour Movement. Manchester: Manchester University Press.

Bauman, Zygmunt (1982): Memories of Class Essays in Pre-History and After-Life of Class. London: Routledge.

Bauman, Zygmunt (1998/2002): Arbejde, forbrugerisme og de nye fattige. København: Hans Reitzels Forlag.

Bauman, Zygmunt (1999): In Search of Politics. Cambridge: Polity Press. at arbejdslivet - for nogle grupper givetvis mere end for andre - opleves som en alt andet end frisættende, inspirerende og mulighedsskabende, og at det - måske endda for store grupper både på og i udkanten af arbejdsmarkedet - opleves som decideret undertryggende og dehumaniserende. Til trods for disse forbehold er der dog ingen tvivl om, at den sociologisk-orienterede arbejdslivsforskning vil vedblive med at lade sig inspirere af sådanne generelle sociologiske forståelser, men det er vigtigt, at disse overordnede og teoretisk funderede samtidsdiagnoser kobles til og diskuteres og vurderes op mod empirisk forskning på feltet.

2 Dette afsnit trækker i vid udstrækning på Jacobsen \& Petersen (2015).

3 På mange måder minder Standings 'prekariat' således om Bauman føromtalte forståelse af 'forspildte liv' (Bauman 2004/2005).

Bauman, Zygmunt (2000/2006): Flydende modernitet. København: Hans Reitzels Forlag.

Bauman, Zygmunt (2004):Arbejdets storhed og fald, i Michael Hviid Jacobsen \& Jens Tonboe (red.): Arbejdssamfundet - den beslaglagte tid og den splittede identitet. København: Hans Reitzels Forlag, pp. 54-68.

Bauman, Zygmunt (2004/2005): Forspildte liv: Moderniteten og dens udstødte. København: Hans Reitzels Forlag.

Beck, Ulrich (1986/1997): Risikosamfundet - på vej mod en ny modernitet. København: Hans Reitzels Forlag.

Beck, Ulrich (1999/2002): Fagre nye arbejdsverden. København: Hans Reitzels Forlag. 
Beck, Ulrich (2002/2006): Magt og modmagt i den globale tidsalder. København: Hans Reitzels Forlag.

Beck, Ulrich \& Elisabeth Beck-Gernsheim (2001): Individualization. London: Sage Publications.

Beck, Ulrich \& Wolfgang Bon $\beta$ (red.) (2001): Die Modernisierung der Moderne. Frankfurt am Main: Suhrkamp.

Bourdieu, Pierre (1998): La précarité est aujourd'hui partout, i Contre-feux. Grenoble: Liber Raisons d'agir, pp. 95-101.

Butler, Judith (2004): Precarious Life: The Powers of Mourning and Violence. London: Verso.

Cameron, William B. \& Thomas C. McCormick (1954): Concepts of Security and Insecurity. American Journal of Sociology, 59 (6):556-564.

Engels, Friedrich (1845/1987): The Conditions of the Working Class in England. Harmondsworth: Penguin Books.

Fisher, Cynthia D. \& Neal M. Ashkanasy (2000): The Emerging Role of Emotions in Work Life: An Introduction. Journal of Organizational Behavior, 21:123-129.

Habermas, Jürgen (1987): The Theory of Communicative Action. Boston: Beacon Press.

Hesseldal, Sarah (2016): Står de unge over for et arbejdsliv uden sikkerhedsnet?. Berlingske, den 14. maj. Tilgængelig online p: http:// www.b.dk/nationalt/staar-de-unge-over-foret-arbejdsliv-uden-sikkerhedsnet.

Hochschild, Arlie R. (1983): The Managed Heart: Commercialization of Human Feeling. Berkeley, CA: University of California Press.

Hochschild, Arlie R. (1997/2003): Tidsfoelden: Når familie bliver arbejde og arbejdet bliver familie. København: Munksgaard.

Hochschild, Arlie R. (2003): The Commercialization of Intimate Life: Notes from Home and Work. San Francisco: University of California Press.

Hochschild, Arlie R. (2004): Gennem sprækker i tidsfælden - fra markedsmanagement til familiemanagement, i Michael Hviid Jacobsen \& Jens Tonboe (red.): Arbejdssamfundet - den beslaglagte tid og den splittede identitet. København: Hans Reitzels Forlag, pp. 109-130.

Illouz, Eva (2008): Saving the Modern Soul: Therapy, Emotions and the Culture of Self-Help. Ber- keley, CA: University of California Press. Jacobsen, Michael Hviid (2004): Fra moderne arbejdsetik til senmoderne selvvalgt slaveri? En kritisk analyse af arbejdets betydning hos Bauman, Beck og Sennett, i Michael Hviid Jacobsen \& Jens Tonboe (red.): Arbejdssamfundet - den beslaglagte tid og den splittede identitet. København: Hans Reitzels Forlag, pp. 69-108.

Jacobsen, Michael Hviid (2007a): Review essay: En (u)passende mængde pessimisme? - om dystre sociologiske samtidsdiagnoser over arbejdslivet. Tidsskrift for Arbejdsliv, 9 (2):108122.

Jacobsen, Michael Hviid Jacobsen (2007b): Til arbejdet, liv eller død! - om arbejdets ambivalens i en flydende moderne verden, i Joel Haviv (red.): Medarbejder eller modarbejder religion i moderne arbejdsliv. Århus: Klim, pp. 25-54.

Jacobsen, Michael Hviid \& Anders Petersen (2015): Kølig kapitalisme - Arlie R. Hochschilds og Eva Illouz' følelsesfeministiske kritik af kommercialiseringen af arbejdsliv, familieliv og kærlighedsliv, i Michael Hviid Jacobsen \& Anders Petersen (red.): Kritik klassiske og kontemporoere sociologiske perspektiver. København: Hans Reitzels Forlag, pp. 227-254.

Jacobsen, Michael Hviid \& Jens Tonboe (red.) (2004): Arbejdssamfundet - den beslaglagte tid og den splittede identitet. København: Hans Reitzels Forlag.

Lorey, Isabell (2015): State of Insecurity: Government of the Precarious. London: Verso.

Mills, Charles Wright (1959/2002): Den sociologiske fantasi. København: Hans Reitzels Forlag.

Nickelsen, Niels Christian Mossfeldt (red.) (2013): Arbejdslivets skyggesider. Århus: Klim.

Petersen, Anders (2016): Proestationssamfundet. København: Hans Reitzels Forlag.

Rosa, Hartmut (2014): Fremmedgørelse og acceleration. København: Hans Reitzels Forlag.

Rasborg, Klaus (2003): Sociologien som samtidsdiagnose, i Michael Hviid Jacobsen (red.): Sociologiske visioner: Sytten bidrag fra en sociologisk brydningstid. Århus: Systime Academic, pp. 120-132.

Sennett, Richard (1992): The Fall of Public Man. 
New York: W. W. Norton \& Co.

Sennett, Richard (1998/1999): Det fleksible menneske - eller arbejdets forvandling og personlighedens nedsmeltning. Højbjerg: Hovedland.

Sennett, Richard (2003): Respect: The Formation of Character in a World of Inequality. Harmondsworth: Penguin Books.

Sennett, Richard (2006): The Culture of the New Capitalism. New Haven: Yale University Press.

Sennett, Richard \& Jonathan Cobb (1972): The Hidden Injuries of Class. New York: W. W. Norton \& Company.

Skoczylas, Tomasz \& Adam Mrozowicki (2012): "Review of The Precariat: The New Dangerous Class, by Guy Standing". Labor History, 53 (4):588-590.
Standing, Guy (2011): The Precariat - The New Dangerous Class. Tilgængelig online på: www.policy-network.net.

Standing, Guy (2012a): The Precariat: The New Dangerous Class. London: Bloomsbury Academic.

Standing, Guy (2012b): "The Precariat: From Denizens to Citizens?". Polity, 44 (4):588608.

Standing, Guy (2014): A Precariat Charter: From Denizens to Citizens. London: Bloomsbury Academic.

Vail, John, Jane Wheelock \& Michael Hill (red.) (1999): Insecure Times: Living with Insecurity in Contemporary Society. London: Routledge.

Zinn, Jens O. (red.) (2008): Social Theories of Risk and Uncertainty: An Introduction. Oxford: Blackwell.

Michael Hviid Jacobsen, Professor, Ph.d., Institut for Sociologi og Socialt Arbejde, Aalborg Universitet

e-mail:mhj@socsci.aau.dk

Anders Petersen, Lektor, Institut for Sociologi og Socialt Arbejde, Aalborg Universitet e-mail: apt@socsci.aau.dk 